\title{
Integrasi SMOTE pada Naive Bayes dan Logistic Regression Berbasis Particle Swarm Optimization untuk Prediksi Cacat Perangkat Lunak
}

\author{
Andre Hardoni ${ }^{\mathrm{a}}$, Dian Palupi Rini ${ }^{\mathrm{b} 2}$, Sukemi ${ }^{\mathrm{a}, \mathrm{b} 3}$ \\ ${ }^{a}$ Fakultas Ilmu Komputer, Universitas Sriwijaya \\ Jl. Srijaya Negara, Bukit Besar, Kota Palembang, Sumatera Selatan \\ ${ }^{1}$ andre.hardoni1991@gmail.com \\ ${ }^{3}$ sukemi@unsri.ac.id \\ ${ }^{b}$ Universitas Sriwijaya \\ Jl. Srijaya Negara, Bukit Besar, Kota Palembang, Sumatera Selatan \\ ${ }^{2}$ dprini@unsri.ac.id
}

\begin{abstract}
Abstrak
Menurut sedano, ralph dan praire cacat perangkat lunak merupakam salah satu penyumbang utama pada limbah teknologi informasi dan menyebabkan pengerjaan ulang, sehingga menghabiskan banyak waktu dan biaya. Prediksi cacat perangkat lunak memiliki tujuan untuk melakukan pencegahan cacat dengan mengklasifikasi kan modul tertentu sebagai cacat atau tidak cacat. Banyak peneliti yang telah melakukan penelitian dibidang cacat perangkat lunak dengan memanfaatkan NASA MDP dataset yang bersifat public, namun dataset-dataset tersebut masih memiliki kekurangan seperti ketidakseimbangan kelas dan noise attribute. Masalah ketidakseimbangan kelas dapat diatasi dengan memanfaatkan SMOTE (Synthetic Minority Over-sampling Technique) dan masalah noise attribute dapat diatasi dengan seleksi fitur dengan memanfaatkan Particle Swarm Optimization (PSO), sehingga pada penelitian ini dilakukan integrasi antara SMOTE dan PSO yang diterapkan pada teknik klasifikasi machine learning naïve bayes dan logistic regression. Dari hasil percobaan yang telah dilakukan pada 8 dataset NASA MDP dengan membagi dataset ke dalam data training dan testing diperoleh hasil bahwa integrasi SMOTE + PSO pada masing-masing teknik klasifikasi dapat meningkatkan kinerja pengklasifikasian dengan nilai AUC (Area Under Curve) tertinggi rata-rata 0,89 pada logistic regression dan 0,86 pada naïve bayes pada pembagian training dantesting 70:30 dan sekaligus lebih baik dibanding dengan tanpa mengkombinasikan keduanya.
\end{abstract}

Kata kunci: cacat perangkat lunak, naïve bayes, logistic regression, SMOTE, PSO

\section{Integration of SMOTE on Naive Bayes and Logistic Regression Based on Particle Swarm Optimization for Software Defect Prediction}

\begin{abstract}
According to Sedano, Ralph and Praire software defects are one of the main contributors to information technology waste and lead to rework, thus consuming a lot of time and money. Software defect prediction has the objective of defect prevention by classifying certain modules as defective or not defective. Many researchers have conducted research in the field of software defect prediction using NASA MDP public datasets, but these datasets still have shortcomings such as class imbalance and noise attribute. The class imbalance problem can be overcome by utilizing SMOTE (Synthetic Minority Over-sampling Technique) and the noise attribute problem can be solved by selecting features using Particle Swarm Optimization (PSO), So in this research, the integration between SMOTE and PSO is applied to the classification technique machine learning naïve Bayes and logistic regression. From the results of experiments that have been carried out on 8 NASA MDP datasets by dividing the dataset into training and testing data, it is found that the SMOTE + PSO integration in each classification technique can improve classification performance with the highest AUC (Area Under Curve) value on average 0,89 on logistic regression and 0,86 in naïve Bayes in the training and testing division 70:30 and at the same time better than without combining the two.
\end{abstract}

Keywords: software defect prediction, naïve bayes, logistic regression, SMOTE, PSO 


\section{Pendahuluan}

Jaminan kualitas perangkat lunak apabila menjadi syarat yang harus dipenuhi perusahaan pengembang perangkat lunak, maka dapat membuat perusahaan lebih kompetitif dalam setiap pembuatan perangkat lunak, namun mempertahankan tingkat kualitas yang tinggi memerlukan pemantauan dan pengembangan secara terus menerus [1]. Kualitas software biasanya diukur dari jumlah cacat yang ada pada produk yang dihasilkan [2]. Cacat merupakan salah satu penyumbang utama pada limbah teknologi informasi dan menyebabkan pengerjaan ulang (rework) proyek sehingga menghabiskan banyak waktu dan biaya [3]. Cacat dapat disebabkan oleh manusia seperti kesalahan dalam kode program, jika cacat dalam kode dieksekusi, sistem mungkin bisa gagal berfungsi dengan baik sehingga menyebabkan kegagalan [4]. Apabila pada akhir proyek cacat ditemukan maka secara sistematis menyebabkan penyelesaian proyek melebihi jadwal [5].

Meningkatan kualitas perangkat lunak dapat dilakukan melalui berbagai cara, namun pendekatan terbaik adalah dengan melakukan pencegahan cacat, karena manfaat dari upaya pencegahannya dapat diterapkan kembali untuk masa depan [6]. Untuk dapat melakukan pencegahan cacat, maka harus dapat memprediksi kemungkinan terjadinya cacat. Teknik klasifikasi merupakan pendekatan yang paling banyak digunakan untuk memprediksi cacat perangkat lunak dan teknik klasifikasi sendiri dapat difokuskan untuk penentuan kelas cacat dan tidak cacat [7]. Sudah banyak penelitian yang menjadikan teknik klasifikasi menjadi topik penelitiannya dengan memanfaatkan algoritma klasifikasi, seperti pada penggunaan algoritma Linear Regression, Logistic Regression (LR), Support Vector Machine (SVM), Nä̈ve Bayes (NB), Random Fores (RF), C4.5, Decision Tree dan Neural Network (NN) [8]. Komparasi algoritma klasifikasi tersebut didapat dua algoritma klasifikasi terbaik yaitu Logistic Regression dan Nä̈ve Bayes [8]. Logistic Regression merupakan teknik klasifikasi yang dapat membuat hasil klasifikasi menjadi powerful pada penanganan masalah klasifikasi banyak kelas [9], sedangkan untuk nä̈ve bayes sendiri merupakan teknik klasifikasi yang efektif, karena memprediksi cacat sebagai klasifikasi biner, membangun prediktor dengan menganalisis historis modul perangkat lunak, berdasarkan prediktor sehingga dapat membuat keputusan apakah modul baru yang terbentuk memiliki cacat atau tidak cacat [10].

Dataset yang memiliki ketidakseimbangan (imbalance) data dan noise attribute adalah beberapa masalah yang ditemukan pada klasifikasi cacat perangkat lunak [11]. Dataset yang tidak seimbang (imbalance) seperti pada dataset NASA National Aeronautics and Space Administration) yang banyak digunakan karena bersifat publik pada penelitian klasifikasi cacat perangkat lunak ditemukan bahwa jumlah data yang tidak cacat (not defect) lebih banyak dari pada jumlah data yang cacat (defect), sehingga hasil klasifikasi cenderung menghasilkan kelas yang banyak yaitu kelas tidak cacat (not defect) [12], selain itu juga dataset berukuran besar dan memiliki banyak kelas atau multi kelas yang ada memiliki noise atau mengandung error, hal ini dapat menyebabkan berkurangnya kinerja pada klasifikasi [13], sehingga perlu untuk melakukan modifikasi teknik klasifikasi dengan menambahkan teknik lain atau menggabungkan algoritma lain untuk menangani masalah tersebut supaya menghasilkan kinerja klasifikasi yang lebih baik.

Penggunaan teknik SMOTE (Synthetic Minority Oversampling Technique) dengan cara kerja SMOTE meduplikasi kelas minoritas dapat menghasilkan hasil yang lebih baik dan cara yang efektif untuk menangani ketidakseimbangan kelas yang mengalami overfitting pada teknik oversampling untuk memproses kelas minoritas [14], sedangkan PSO dapat ditambahkan untuk dikombinasikan dengan SMOTE, karena prinsip kerja PSO sendiri memilih parameter terbaik dan menghindari pemilihan parameter secara tidak teratur dan memiliki tujuan tidak hanya memperbaiki masalah ketidakseimbangan dalam dataset tetapi juga membantu menambahkan jumlah data sintesis yang tepat di kelas minoritas untuk hasil kinerja yang baik [15], sehingga pada penelitian ini yang akan dilakukan yaitu mengintegrasikan SMOTE pada nä̈ve bayes dan Logistic Regression untuk penyelesaian masalah ketidakseimbangan kelas (class imbalance) pada klasifikasi cacat perangkat lunak, dan mengkombinasikan PSO sebagai seleksi atribut untuk mengurangi noise attribute sehingga diharapkan mendapatkan hasil klasifikasi yang terbaik.

\section{METODOLOGI}

\section{A. Metodologi Penelitian}

Penelitian ini menggunakan metode eksperimen. metode eksperimen mencakup investigasi hubungan sebab-akibat menggunakan pengujian yang dikontrol sendiri [16]. Penelitian ini bertujuan untuk mengurangi pengaruh ketidakseimbangan kelas dan noise attribute pada model prediksi cacat perangkat lunak. Pada penelitian ini dilakukan dengan mengikuti tahapan seperti pada gambar berikut.

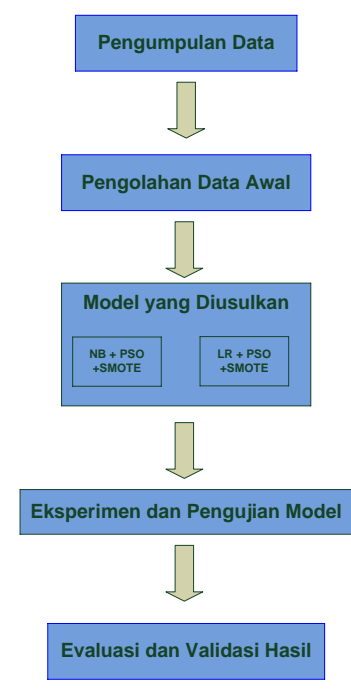

Gambar 1. Tahapan penelitian 
1) Pengumpulan Data: Pada penelitian ini Pada penelitian ini digunakan data sekunder yaitu dari NASA (National Aeronautic and Space Administration) MDP (Metrics Data Program) repository, karena dataset NASA sudah umum digunakan para peneliti untuk membangun model kegagalan perangkat lunak [8]. Adapun spesifikasi dataset yang digunakan adalah seperti pada tabel berikut.

TABEL I

SPESIFIKASI DAN ATRIBUT NASA MDP REPOSITORY

\begin{tabular}{|c|c|c|c|c|c|c|c|c|}
\hline \multirow{2}{*}{$\begin{array}{c}\text { NAMA } \\
\text { ATRIBUT }\end{array}$} & \multicolumn{8}{|c|}{ NASA DATASET MDP REPOSITORY } \\
\hline & CM & $\begin{array}{c}\mathrm{KC} \\
1\end{array}$ & KC & $\underset{2}{\mathrm{MC}}$ & $\begin{array}{c}\mathrm{PC} \\
1\end{array}$ & $\begin{array}{c}\mathbf{P C} \\
2\end{array}$ & $\begin{array}{c}\mathbf{P C} \\
\mathbf{3}\end{array}$ & $\begin{array}{c}\mathrm{PC} \\
4\end{array}$ \\
\hline LOC BLANK & $\sqrt{ }$ & $\sqrt{ }$ & $\sqrt{ }$ & $\sqrt{ }$ & $\sqrt{ }$ & & $\sqrt{ }$ & $\sqrt{ }$ \\
\hline $\begin{array}{l}\text { LOC CODE AND } \\
\text { COMMENT }\end{array}$ & $\sqrt{ }$ & $\sqrt{ }$ & $\sqrt{ }$ & $\sqrt{ }$ & $\sqrt{ }$ & $\sqrt{ }$ & $\sqrt{ }$ & $\sqrt{ }$ \\
\hline LOC COMMENTS & $\sqrt{ }$ & $\sqrt{ }$ & $\sqrt{ }$ & $\sqrt{ }$ & $\sqrt{ }$ & $\sqrt{ }$ & $\sqrt{ }$ & $\sqrt{ }$ \\
\hline LOC EXECUTABLE & $\sqrt{ }$ & $\sqrt{ }$ & $\sqrt{ }$ & $\sqrt{ }$ & $\sqrt{ }$ & $\sqrt{ }$ & $\sqrt{ }$ & $\sqrt{ }$ \\
\hline LOC TOTAL & $\sqrt{ }$ & $\sqrt{ }$ & $\sqrt{ }$ & $\sqrt{ }$ & $\sqrt{ }$ & $\sqrt{ }$ & $\sqrt{ }$ & $\sqrt{ }$ \\
\hline NUMBER OF LINES & $\sqrt{ }$ & & $\sqrt{ }$ & $\sqrt{ }$ & $\sqrt{ }$ & $\sqrt{ }$ & $\sqrt{ }$ & \\
\hline $\begin{array}{l}\text { HALSTEAD } \\
\text { CONTENT }\end{array}$ & $\sqrt{ }$ & $\sqrt{ }$ & $\sqrt{ }$ & $\sqrt{ }$ & $\sqrt{ }$ & $\sqrt{ }$ & $\sqrt{ }$ & $\checkmark$ \\
\hline $\begin{array}{l}\text { HALSTEAD } \\
\text { DIFFICULTY }\end{array}$ & $\sqrt{ }$ & $\sqrt{ }$ & $\sqrt{ }$ & $\sqrt{ }$ & $\sqrt{ }$ & $\sqrt{ }$ & $\sqrt{ }$ & $\sqrt{ }$ \\
\hline HALSTEAD EFFORT & $\sqrt{ }$ & $\sqrt{ }$ & $\sqrt{ }$ & $\sqrt{ }$ & $\sqrt{ }$ & $\sqrt{ }$ & $\sqrt{ }$ & $\sqrt{ }$ \\
\hline $\begin{array}{l}\text { HALSTEAD ERROR } \\
\text { EST }\end{array}$ & $\sqrt{ }$ & $\sqrt{ }$ & $\sqrt{ }$ & $\sqrt{ }$ & $\sqrt{ }$ & $\sqrt{ }$ & $\sqrt{ }$ & $\sqrt{ }$ \\
\hline HALSTEAD LENGTH & $\sqrt{ }$ & $\sqrt{ }$ & $\sqrt{ }$ & $\sqrt{ }$ & $\sqrt{ }$ & $\sqrt{ }$ & $\sqrt{ }$ & $\sqrt{ }$ \\
\hline HALSTEAD LEVEL & $\sqrt{ }$ & $\sqrt{ }$ & $\sqrt{ }$ & $\sqrt{ }$ & $\sqrt{ }$ & $\sqrt{ }$ & $\sqrt{1}$ & $\sqrt{ }$ \\
\hline $\begin{array}{l}\text { HALSTEAD PROG } \\
\text { TIME }\end{array}$ & $\sqrt{ }$ & $\sqrt{ }$ & $\sqrt{ }$ & $\sqrt{ }$ & $\sqrt{ }$ & $\sqrt{ }$ & $\sqrt{ }$ & $\sqrt{ }$ \\
\hline $\begin{array}{l}\text { HALSTEAD } \\
\text { VOLUME }\end{array}$ & $\sqrt{ }$ & $\sqrt{ }$ & $\sqrt{ }$ & $\sqrt{ }$ & $\sqrt{ }$ & $\sqrt{ }$ & $\sqrt{ }$ & $\checkmark$ \\
\hline NUM OPERANDS & $\sqrt{ }$ & $\sqrt{ }$ & $\sqrt{ }$ & $\sqrt{ }$ & $\sqrt{ }$ & $\sqrt{ }$ & $\sqrt{ }$ & $\sqrt{ }$ \\
\hline NUM OPERATORS & $\sqrt{ }$ & $\sqrt{ }$ & $\sqrt{ }$ & $\sqrt{ }$ & $\sqrt{ }$ & $\sqrt{ }$ & $\sqrt{ }$ & $\sqrt{ }$ \\
\hline $\begin{array}{l}\text { NUM UNIQUE } \\
\text { OPERANDS }\end{array}$ & $\sqrt{ }$ & $\sqrt{ }$ & $\sqrt{ }$ & $\sqrt{ }$ & $\checkmark$ & $\sqrt{ }$ & $\sqrt{ }$ & $\sqrt{ }$ \\
\hline $\begin{array}{l}\text { NUM UNIQUE } \\
\text { OPERATORS }\end{array}$ & $\sqrt{ }$ & $\sqrt{ }$ & $\sqrt{ }$ & $\sqrt{ }$ & $\sqrt{ }$ & $\checkmark$ & $\sqrt{ }$ & $\checkmark$ \\
\hline $\begin{array}{l}\text { CYCLOMATIC } \\
\text { COMPLEXITY }\end{array}$ & $\sqrt{ }$ & $\sqrt{ }$ & $\sqrt{ }$ & $\sqrt{ }$ & $\sqrt{ }$ & $\checkmark$ & $\sqrt{ }$ & $\checkmark$ \\
\hline $\begin{array}{l}\text { CYCLOMATIC } \\
\text { DENSITY }\end{array}$ & $\sqrt{ }$ & & $\sqrt{ }$ & $\sqrt{ }$ & $\sqrt{ }$ & $\checkmark$ & $\sqrt{ }$ & $\checkmark$ \\
\hline $\begin{array}{l}\text { DESIGN } \\
\text { COMPLEXITY }\end{array}$ & $\sqrt{ }$ & $\sqrt{ }$ & $\sqrt{ }$ & $\sqrt{ }$ & $\sqrt{ }$ & $\checkmark$ & $\sqrt{ }$ & $\sqrt{ }$ \\
\hline $\begin{array}{l}\text { ESSENTIAL } \\
\text { COMPLEXITY }\end{array}$ & $\sqrt{ }$ & $\sqrt{ }$ & $\sqrt{ }$ & $\sqrt{ }$ & $\sqrt{ }$ & $\checkmark$ & $\sqrt{ }$ & $\sqrt{ }$ \\
\hline BRANCH COUNT & $\sqrt{ }$ & $\sqrt{ }$ & $\sqrt{ }$ & $\sqrt{ }$ & $\sqrt{ }$ & $\sqrt{ }$ & $\sqrt{ }$ & $\sqrt{ }$ \\
\hline CALL PAIRS & $\sqrt{ }$ & & $\sqrt{ }$ & $\sqrt{ }$ & $\sqrt{ }$ & $\sqrt{ }$ & $\sqrt{ }$ & $\sqrt{ }$ \\
\hline CONDITION COUNT & $\sqrt{ }$ & & $\sqrt{ }$ & $\sqrt{ }$ & $\sqrt{ }$ & $\sqrt{ }$ & $\sqrt{ }$ & $\sqrt{ }$ \\
\hline DECISION COUNT & $\sqrt{ }$ & & $\sqrt{ }$ & $\sqrt{ }$ & $\sqrt{ }$ & $\sqrt{ }$ & $\sqrt{ }$ & $\sqrt{ }$ \\
\hline DECISION DENSITY & $\sqrt{ }$ & & $\sqrt{ }$ & $\sqrt{ }$ & $\sqrt{ }$ & $\frac{v}{v}$ & $\frac{v}{\sqrt{ }}$ & $\sqrt{ }$ \\
\hline DESIGN DENSITY & $\sqrt{ }$ & & $\sqrt{ }$ & $\sqrt{ }$ & $\sqrt{ }$ & $\sqrt{ }$ & $\sqrt{ }$ & $\sqrt{ }$ \\
\hline EDGE COUNT & $\sqrt{ }$ & & $\sqrt{ }$ & $\sqrt{ }$ & $\sqrt{ }$ & $\sqrt{ }$ & $\sqrt{ }$ & $\sqrt{ }$ \\
\hline $\begin{array}{l}\text { ESSENTIAL } \\
\text { DENSITY }\end{array}$ & $\sqrt{ }$ & & $\sqrt{ }$ & $\checkmark$ & $\sqrt{ }$ & $\sqrt{ }$ & $\sqrt{ }$ & $\sqrt{ }$ \\
\hline $\begin{array}{l}\text { GLOBAL DATA } \\
\text { COMPLEXITY }\end{array}$ & & & $\sqrt{ }$ & $\sqrt{ }$ & & & & \\
\hline $\begin{array}{l}\text { GLOBAL DATA } \\
\text { DENSITY }\end{array}$ & & & $\sqrt{ }$ & $\sqrt{ }$ & & & & \\
\hline $\begin{array}{l}\text { MAINTENANCE } \\
\text { SEVERITY }\end{array}$ & $\sqrt{ }$ & & $\sqrt{ }$ & $\sqrt{ }$ & $\checkmark$ & $\sqrt{ }$ & $\sqrt{ }$ & $\checkmark$ \\
\hline $\begin{array}{l}\text { MODIFIED } \\
\text { CONDITION COUNT }\end{array}$ & $\sqrt{ }$ & & $\sqrt{ }$ & $\sqrt{ }$ & $\sqrt{ }$ & $\sqrt{ }$ & $\sqrt{ }$ & $\sqrt{ }$ \\
\hline $\begin{array}{l}\text { MULTIPLE } \\
\text { CONDITION COUNT }\end{array}$ & $\sqrt{ }$ & & $\sqrt{ }$ & $\sqrt{ }$ & $\sqrt{ }$ & $\sqrt{ }$ & $\sqrt{ }$ & $\sqrt{ }$ \\
\hline NODE COUNT & $\sqrt{ }$ & & $\sqrt{ }$ & $\sqrt{ }$ & $\sqrt{ }$ & $\sqrt{ }$ & $\sqrt{ }$ & $\sqrt{ }$ \\
\hline $\begin{array}{l}\text { NORMALIZED } \\
\text { CYLOMATIC } \\
\text { COMPLEXITY }\end{array}$ & $\sqrt{ }$ & & $\sqrt{ }$ & $\sqrt{ }$ & $\sqrt{ }$ & $\sqrt{ }$ & $\sqrt{ }$ & $\checkmark$ \\
\hline $\begin{array}{l}\text { PARAMETER } \\
\text { COUNT }\end{array}$ & $\sqrt{ }$ & & $\sqrt{ }$ & $\sqrt{ }$ & $\sqrt{ }$ & $\sqrt{ }$ & $\sqrt{ }$ & $\checkmark$ \\
\hline $\begin{array}{l}\text { PERCENT } \\
\text { COMMENTS }\end{array}$ & $\sqrt{ }$ & & $\sqrt{ }$ & $\sqrt{ }$ & $\sqrt{ }$ & $\sqrt{ }$ & $\sqrt{ }$ & $\sqrt{ }$ \\
\hline $\begin{array}{l}\text { PATHOLOGICAL } \\
\text { COMPLEXITY }\end{array}$ & & & & & & & & \\
\hline DEFECTIVE & $\sqrt{ }$ & $\sqrt{ }$ & $\sqrt{ }$ & $\sqrt{ }$ & $\sqrt{ }$ & $\sqrt{ }$ & $\sqrt{ }$ & $\sqrt{ }$ \\
\hline
\end{tabular}

2) Pengolahan Data Awal: Pada tahapan ini dilakukan validasi data yang digunakan untuk mengidentifikasi dan menghapus data yang ganjil dan data yang tidak lengkap. Total record data yang digunakan pada penelitian ini akan ditampilkan pada tabel berikut.

TABEL II

TOTAL RECORD DATA YANG DIGUNAKAN

\begin{tabular}{|c|c|c|c|c|}
\hline Dataset & $\begin{array}{c}\text { Jumlah } \\
\text { Atribut }\end{array}$ & $\begin{array}{c}\text { Jumlah } \\
\text { Modul }\end{array}$ & $\begin{array}{c}\text { Jumlah } \\
\text { Modul Cacat }\end{array}$ & $\begin{array}{c}\text { Jumlah Modul } \\
\text { Tidak Cacat }\end{array}$ \\
\hline CM1 & 38 & 344 & 42 & 202 \\
\hline KC1 & 22 & 2095 & 325 & 1770 \\
\hline KC3 & 40 & 200 & 36 & 164 \\
\hline MC2 & 40 & 125 & 44 & 81 \\
\hline MW1 & 38 & 263 & 27 & 236 \\
\hline PC1 & 38 & 735 & 61 & 674 \\
\hline PC2 & 37 & 1493 & 16 & 1477 \\
\hline PC3 & 38 & 1099 & 138 & 961 \\
\hline PC4 & 38 & 1379 & 178 & 1201 \\
\hline
\end{tabular}

3) Model yang Diusulkan: untuk mencari solusi masalah ketidakseimbangan kelas dan noise attribute pada dataset software metrics, diusulkan model dengan teknik resampling data dan seleksi fitur. Perancangan model yang diusulkan meliputi kerangka kerja model penelitian yang dapat dilihat pada gambar berikut.

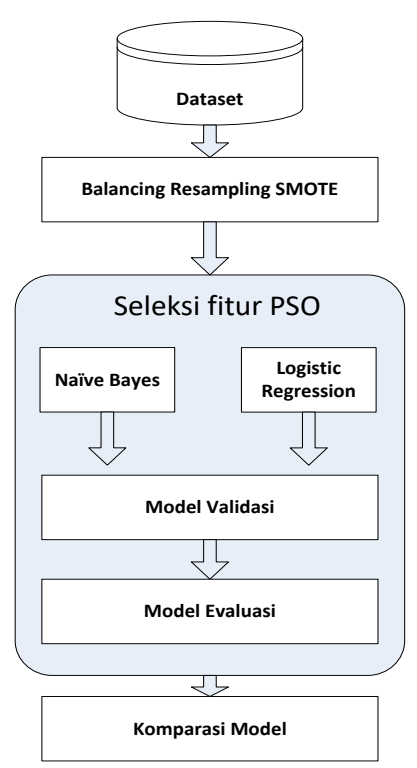

Gambar 2. Kerangka kerja model yang diusulkan

Proses pengujian model diawali dari dataset awal yang masih belum seimbang antara kelas cacat dan tidak cacat dengan menggunkaan teknik SMOTE data diolah dan hasil dari keluaran tersebut kemudian diproses dengan membagi data tersebut kedalam dua bagian yaitu training dan testing dengan perbandingan 50:50, 60:40, dan 70: 30, kemudian dengan memanfaatkan teknik PSO sebagai seleksi fitur untuk menyeleksi fitur yang gunakan dan melalui nilai fitnes dari model logistic regression dan naive bayes didapat nilai pbest dan gbest yang selanjutnya digunakan untuk memntukan posisi partikel yang nantinya akan digunkan sebagai seleksi fitur. Kemudian hal tersebut berulang hingga mencapai itersi yang diinginkan dan hasil yang paling masksimal tersebut sebagai hasil yang digunakan untuk dilakukan validasi dan evaluasi, sehingga didapat model terbaik dengan komparasi. 
4) Eksperimen dan Pengujian Model: Pada tahap ini dilakukan pengujian terhadap model data mining dengan simulasi model yang telah dirancang dan telah dilakukan pengkodingan dengan memanfaatkan tools dan bahasa pemrograman sehingga mendapatkan hasil dari pengujian tersebut.

5) Evaluasi dan Validasi Hasil: Pengukuran kinerja model dilakukan dengan menggunakan confusion matrix. Kinerja yang diukur yaitu nilai AUC (Area Under Curve). Confusion matrix diperoleh dari validasi, sehingga model yang terbentuk dapat langsung diuji dengan melakukan pembagian antara data testing dan training. Kinerja model yang diperoleh digunakan untuk membandingkan antara model dasar algoritma nä̈ve bayes dan logistic regression dengan model yang dibentuk menggunakan algoritma naïve bayes dan logistic regression SMOTE dan PSO. Untuk melihat kualitas model dihasilkan, nilai AUC dapat dijadiakan ukuran untuk melihat model yang terbentuk.

\section{B. Landasan Teori}

1) Cacat Perangkat Lunak: cacat adalah suatu karakteristik yang mengurangi kegunaan atau value suatu item atau semacam kelemahan, ketidaksempurnaan, atau kekurangan [1]. Cacat perangkat lunak merupakan segala cacat atau ketidaksempurnaan di dalam produk perangkat lunak (program komputer, perencanaan, dokumentasi terkait, atau data) atau proses perangkat lunak (aktivitas, metode dan transformasi yang digunakan untuk mengembangkan dan mengelola produk perangkat lunak) [17]. Cacat perangkat lunak dapat menjadi penyebab kegagalan perangkat lunak, yang terjadi ketika pengguna mengalami perilaku sistem yang tidak diinginkan pada titik waktu tertentu. Bagi user, cacat perangkat lunak adalah segala kekurangan yang menyebabkan perangkat lunak tidak dapat memenuhi apa yang diharapkan [5].

2) Naive Bayes: salah satu algoritma klasifikasi yang paling efektif dan efisien [10]. Nä̈ve Bayes merupakan salah satu metode machine learning yang menggunakan metode probabilitas. Probabilitas keanggotaan dapat diprediksi oleh pengklasifikasi dan proses didasarkan pada teorema bayes [18]. Untuk klasifikasi dengan data kontinyu digunakan rumus Densitas Gauss [19] :

$\mathrm{P}\left(X_{\bar{i}}=x_{i} \mid Y_{i}=y_{\bar{i}}\right)=\frac{1}{\sqrt{2 \pi \sigma i j}} e^{-\frac{\left(x_{i}-\mu_{i j}\right)^{3}}{2 \sigma^{2} i j}}$

Dimana :

$\mathrm{P} \quad$ : Peluang

$X_{i} \quad:$ Atribut ke -i

$X_{i} \quad$ : Nilai atribut ke $-\mathrm{i}$

$Y_{i} \quad$ : Kelas yang dicari

$y_{i} \quad$ : Nilai parameter $Y_{i}$

$\mu \quad$ : Nilai mean

$\sigma \quad:$ Standar deviasi

3) Logistic Regression: logistic regression mempunyai tujuan yaitu mendapatkan model yang sederhana dan terbaik untuk menjelaskan hubungan antara output dari variabel respon $(Y)$ dengan variabel - variabel prediktornya $(X)[20]$

Secara umum menurut Hosmer, D.W. dan Lameshow, S. didalam [21] model regresi logistik yaitu :

$\pi(\mathrm{x})=\frac{\exp (\beta 0+\beta 1 \mathrm{x} 1+\beta 2 \mathrm{x} 2+\cdots+\beta \mathrm{pxp})}{1+\exp (\beta 0+\beta 1 \mathrm{x} 1+\beta 2 \mathrm{x} 2+\cdots+\beta \mathrm{pxp})}$

Dimana

$\pi(\mathrm{x})$ :Variabel respon yang memiliki dua kemungkinan (1 atau 0 )

$\beta \quad$ : Parameter nilai koefisien $\beta$

$\mathrm{X} \quad$ : Variabel bebas

4) Sintesis Kelas Minoritas: Menurut chawla didalam [22] SMOTE (Synthetic Minority Over-sampling Technique) merupakan pendekatan oversampling pada kelas minoritas yaitu dengan melakukan oversampling untuk menciptakan sampel "sintetik" bukan dengan oversampling penggantian. Dengan memanfaatkan jumlah prosentase nilai $\mathrm{k}$ tetangga untuk mensitesis kelas minoritas [23].

5) Particle Swarm Optimization: Menurut [24] untuk memulai algoritma PSO, kecepatan awal (velocity) dan posisi awal (position) ditentukan secara random. Kemudian proses pengembangannya sebagai berikut :

a. Asumsikan ukuran kawanan (jumlah pertikel)

b. Hitung kecepatan dari semua partikel.

c. Nilai fitness setiap partikel ditaksir menurut fungsi sasaran (objective function) yang ditetapkan.

d. Nilai fitness partikel dibandingkan dengan Gbest. Jika Gbest yang terbaik maka Gbest yang di update.

e. Perbaharui (update) kecepatan (velocity) dan posisi (position) setiap partikel.

f. Cek apakah solusi yang sekarang sudah konvergen. Jika posisi semua partikel menuju ke satu nilai yang sama, maka ini disebut konvergen. Jika belum konvergen maka langkah 2 diulang dengan memperbarui iterasi $\mathrm{i}=\mathrm{i}+1$, dengan cara menghitung nilai baru dari Pbest dan Gbest. Proses iterasi ini dilanjutkan sampai pada maksimum iterasi.

6) Confusion Matrix: merupakan alat ukur yang berguna untuk menganalisa seberapa baik pengklasifikasi dapat mengenali fitur dari kelas yang berbeda [13]. Confusion matrix merupakan matrik 2 dimensi yang menggambarkan perbandingan antara hasil prediksi dengan kenyataan seperti ditunjukan pada gambar gambar berikut [25].

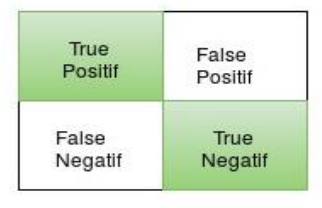

Gambar 3. Confusion Matrix

True Positive (TP) adalah jika nilai prediksi benar dan nilai sebenarnya benar, False Positive (FP) adalah jika nilai prediksi benar dan nilai sebenarnya salah. False Negative (FN) adalah jika nilai prediksi salah dan nilai sebenarnya salah. True Negative (TN) adalah jika nilai prediksi salah dan nilai sebenarnya benar. 
7) AUC (Area Under Curve): yaitu ukuran numerik yang dipakai sebagai pembanding kinerja model dan sebegai tolak ukur seberapa berhasil sekaligus benar peringkat dari model yang dibandingkan dengan menggunakan pemisahan antara rate positif dan negatif [26]. AUC merupakan ukuran kinerja yang paling banyak digunakan dalam kasus ketidakseimbangan kelas. Dengan nilai AUC yang tinggi menunjukkan kinerja suatu model yang lebih baik [27]. Sehingga untuk model yang terbaik pada prediksi cacat perangkat lunak ini dapat ditentukan dengan menganalisa nilai AUC.

\section{HASIL DAN PEMBAHASAN}

Pada percobaan ini menggunakan 8 dataset NASA MDP yang pada proses penelitian dibagi dalam dua bagian yaitu training dan testing dengan memanfaatkan metode pembagian data training dan testing 50:50, 60:40 dan 70:30 dan dengan skenario yang sama pada perlakuan PSO yaitu jumlah partikel : 10, iterasi : 30 . Evaluasi hasil dari penelitian menggunakan hasil dari nilai AUC sebagai indikator hasil akurasi dari performa prediksi model. Hasil dari percobaan tersebut dapat dilihat pada tabel hasil uji coba.

\section{A. Uji coba dengan menggunakan data training dan testing $50: 50$}

Berikut hasil uji coba dilakukan dengan menggunakan data training 50\% dan testing 50\% dangan nilai AUC pada masing masing dataset.

TABEL III

HASIL PENGUKURAN NILAI AUC PADA UJI COBA 50:50

\begin{tabular}{|l|c|c|c|c|c|c|c|c|}
\hline \multirow{2}{*}{ Model } & \multicolumn{7}{|c|}{ Dataset } \\
\cline { 2 - 9 } & CM1 & KC1 & KC3 & MC2 & PC1 & PC2 & PC3 & PC4 \\
\hline NB & 0,73 & 0.77 & 0,71 & 0,71 & 0,76 & 0,60 & 0,74 & 0,79 \\
\hline LR & 0,70 & 0,79 & 0,61 & 0,62 & 0,78 & 0,71 & 0,78 & 0,9 \\
\hline NB+SMOTE & 0,77 & 0,78 & 0,73 & 0,72 & 0,80 & 0,93 & 0,79 & 0,87 \\
\hline LR+SMOTE & 0,76 & 0,79 & 0,84 & 0,60 & 0,77 & 0,97 & 0,83 & 0,91 \\
\hline NB +PSO & 0,81 & 0,79 & 0,75 & 0,76 & 0,82 & 0,89 & 0,84 & 0,87 \\
\hline LR +PSO & 0,74 & 0,80 & 0,69 & 0,67 & 0,86 & 0,92 & 0,81 & 0,92 \\
\hline $\begin{array}{l}\text { NB+SMOTE+ } \\
\text { PSO }\end{array}$ & 0,84 & 0,80 & 0,84 & 0,83 & 0,81 & 0,95 & 0,85 & 0,88 \\
\hline $\begin{array}{l}\text { LR+SMOTE+ } \\
\text { PSO }\end{array}$ & 0,85 & 0,81 & 0,85 & 0,75 & 0,86 & 0,98 & 0,86 & 0,93 \\
\hline
\end{tabular}

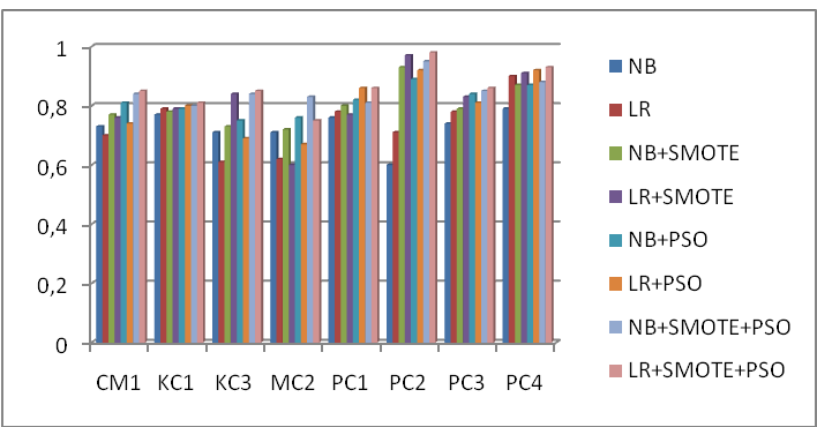

Gambar 4. Grafik hasil pengukuran AUC uji coba 50:50

Pada tabel 3 dan gambar 4 di atas dapat kita lihat perbandingan nilai AUC pada masing masing dataset.
Diketahui dari masing masing dataset tersebut terlihat bahwa untuk model yang diusulkan hampir pada setiap dataset menunjukan hasil yang lebih baik dibandingkan dengan model yang lain dengan menggunakan teknik klasifikasi dasar yang sama, namun untuk naive bayes+SMOTE+PSO ada dataset yang masih belum terlalu signifikan perubahan seperti pada dataset PC1 dimana nilai AUC model yang diusulkan 0,81 lebih kecil dari nilai $\mathrm{NB}+\mathrm{PSO} 0,82$, namun untuk mengkomparasi model secara keseluruhan dapat kita lihat pada grafik nilai AUC rata rata sebagai berikut.

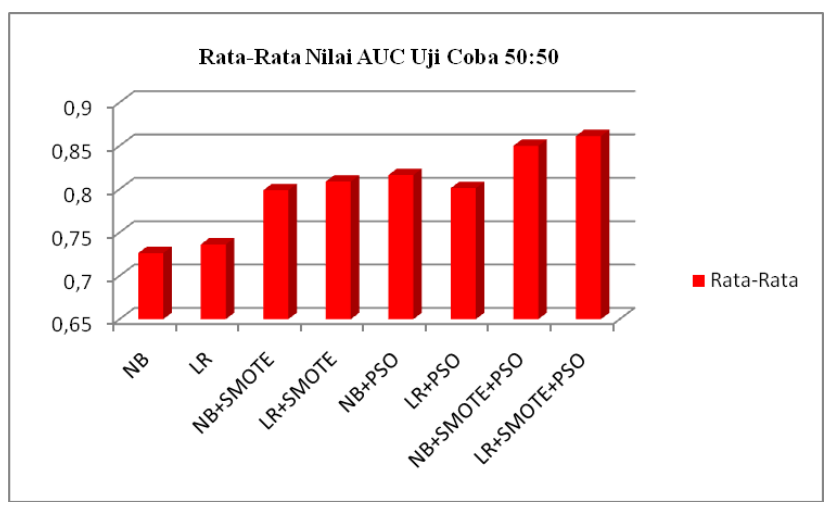

Gambar 5. Rata-rata nilai AUC uji coba 50:50

Pada gambar 5 di atas dapat kita lihat jika model yang diusulkan memiliki nilai AUC rata-rata lebih baik daripada model lainnya dengan rata-rata nilai AUC pada naive bayes + SMOTE + PSO sebesar 0,85 dan LR+SMOTE+PSO sebesar 0,86.

\section{B. Uji coba dengan menggunakan data training dan data testing 60:40}

Berikut hasil uji coba dilakukan dengan menggunakan data training $60 \%$ dan testing $40 \%$ dangan nilai AUC pada masing masing dataset.

TABEL IV

HASIL PENGUKURAN NILAI AUC PADA UJI COBA 60:40

\begin{tabular}{|l|c|c|c|c|c|c|c|c|}
\hline \multirow{2}{*}{ Model } & \multicolumn{7}{|c|}{ Dataset } \\
\cline { 2 - 9 } & CM1 & KC1 & KC3 & MC2 & PC1 & PC2 & PC3 & PC4 \\
\hline NB & 0,71 & 0,78 & 0,57 & 0,66 & 0,77 & 0,84 & 0,79 & 0,8 \\
\hline LR & 0,81 & 0,8 & 0,55 & 0,76 & 0,73 & 0,86 & 0,79 & 0,9 \\
\hline NB+SMOTE & 0,78 & 0,79 & 0,75 & 0,78 & 0,8 & 0,93 & 0,78 & 0,88 \\
\hline LR+SMOTE & 0,83 & 0,8 & 0,77 & 0,67 & 0,85 & 0,97 & 0,86 & 0,91 \\
\hline NB +PSO & 0,73 & 0,79 & 0,79 & 0,85 & 0,77 & 0,89 & 0,8 & 0,88 \\
\hline LR +PSO & 0,73 & 0,82 & 0,84 & 0,78 & 0,85 & 0,91 & 0,84 & 0,92 \\
\hline $\begin{array}{l}\text { NB+SMOTE+ } \\
\text { PSO }\end{array}$ & 0,85 & 0,82 & 0,81 & 0,76 & 0,83 & 0,94 & 0,82 & 0,89 \\
\hline $\begin{array}{l}\text { LR+SMOTE+ } \\
\text { PSO }\end{array}$ & 0,87 & 0,81 & 0,87 & 0,82 & 0,85 & 0,98 & 0,87 & 0,93 \\
\hline
\end{tabular}




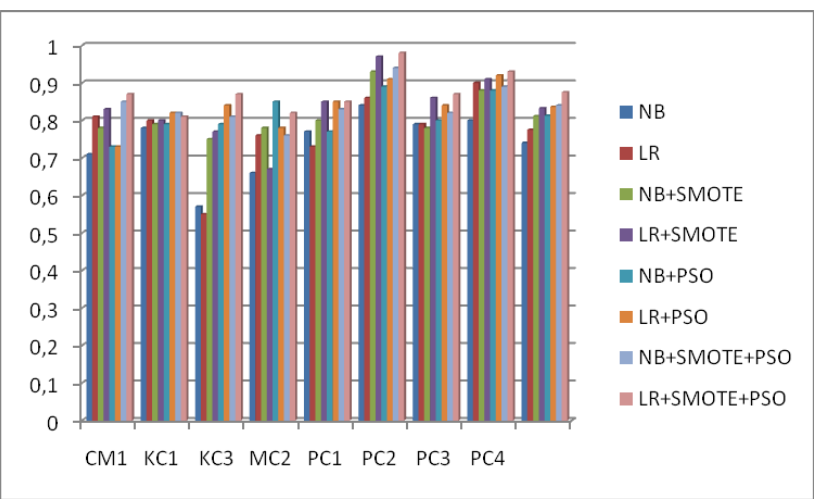

Gambar 6. Grafik hasil pengukuran AUC uji coba 60:40

Pada tabel 4 dan gambar 6 di atas dapat kita lihat perbandingan nilai AUC pada masing masing dataset. Diketahui dari masing masing dataset tersebut terlihat bahwa untuk model yang diusulkan hampir pada setiap dataset menunjukan hasil yang lebih baik dibandingkan dengan model yang lain dengan menggunakan teknik klasifikasi dasar yang sama, namun ada beberapa dataset yang nilai AUCnya masih belum terlalu signifikan seperti pada dataset KC1 untuk LR+SMOTE+PSO dimana nilai AUC model yang diusulkan 0,81 sementara LR+PSO 0,82. Untuk NB+SMOTE+PSO pada MC2 dimana nilai AUC model yang diusulkan 0,76 sedangkan NB+SMOTE 0,78 dan NB+PSO 0,85, namun untuk mengkomparasi model secara keseluruhan dapat kita lihat pada grafik nilai AUC rata rata sebagai berikut.

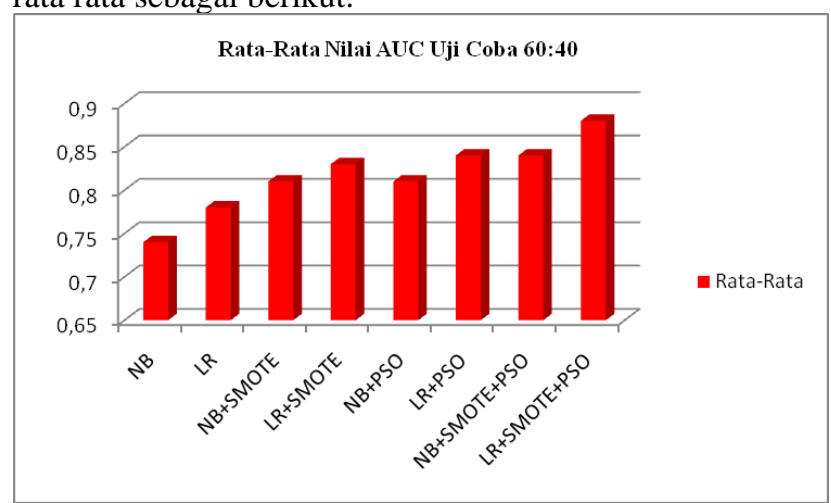

Gambar 7. Grafik rata-rata nilai AUC uji coba 60:40

Pada gambar 7 di atas dapat kita lihat jika model yang diusulkan memiliki nilai AUC rata-rata lebih baik daripada model lainnya dengan rata-rata nilai AUC pada naive bayes + SMOTE + PSO sebesar 0,84 dan LR+SMOTE+PSO sebesar 0,88 .

\section{Uji coba dengan menggunakan data training dan data testing 70:30}

Berikut hasil uji coba dilakukan dengan menggunakan data training $70 \%$ dan testing $30 \%$ dangan nilai AUC pada masing masing dataset.

TABEL $V$

HASIL PENGUKURAN NILAI AUC PADA UJI COBA 60:40

\begin{tabular}{|c|c|c|c|c|c|c|c|c|}
\hline \multirow{3}{*}{ Model } & \multicolumn{7}{|c|}{ Dataset } \\
\cline { 2 - 8 } & CM1 & KC1 & KC3 & MC2 & PC1 & PC2 & PC3 & PC4 \\
\hline
\end{tabular}

\begin{tabular}{|l|c|c|c|c|c|c|c|c|}
\hline NB & 0,71 & 0,78 & 0,57 & 0,66 & 0,77 & 0,84 & 0,79 & 0,8 \\
\hline LR & 0,81 & 0,8 & 0,55 & 0,76 & 0,73 & 0,86 & 0,79 & 0,9 \\
\hline NB+SMOTE & 0,78 & 0,79 & 0,75 & 0,78 & 0,8 & 0,93 & 0,78 & 0,88 \\
\hline LR+SMOTE & 0,83 & 0,8 & 0,77 & 0,67 & 0,85 & 0,97 & 0,86 & 0,91 \\
\hline NB +PSO & 0,73 & 0,79 & 0,79 & 0,85 & 0,77 & 0,89 & 0,8 & 0,88 \\
\hline LR+PSO & 0,73 & 0,82 & 0,84 & 0,78 & 0,85 & 0,91 & 0,84 & 0,92 \\
\hline $\begin{array}{l}\text { NB+SMOTE+ } \\
\text { PSO }\end{array}$ & 0,85 & 0,82 & 0,81 & 0,76 & 0,83 & 0,94 & 0,82 & 0,89 \\
\hline $\begin{array}{l}\text { LR+SMOTE+ } \\
\text { PSO }\end{array}$ & 0,87 & 0,81 & 0,87 & 0,82 & 0,85 & 0,98 & 0,87 & 0,93 \\
\hline
\end{tabular}

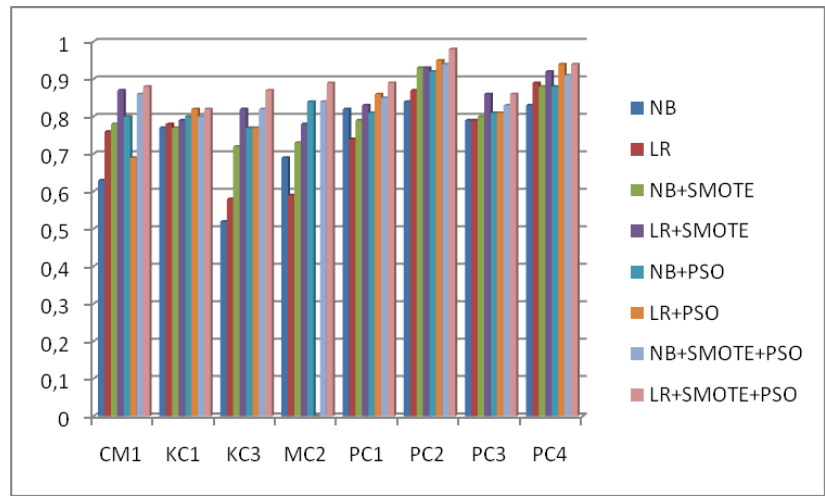

Gambar 8. Grafik hasil pengukuran AUC uji coba 70:40

Pada tabel 5 dan gambar 8 di atas dapat kita lihat perbandingan nilai AUC pada masing masing dataset. Diketahui dari masing masing dataset tersebut terlihat bahwa untuk model yang diusulkan hampir pada setiap dataset menunjukan hasil yang lebih baik dibandingkan dengan model yang lain dengan menggunakan teknik klasifikasi dasar yang sama baik itu pada naive bayes maupun logistic regression. Untuk mengkomparasi model secara keseluruhan dapat kita lihat pada grafik nilai AUC rata rata sebagai berikut.

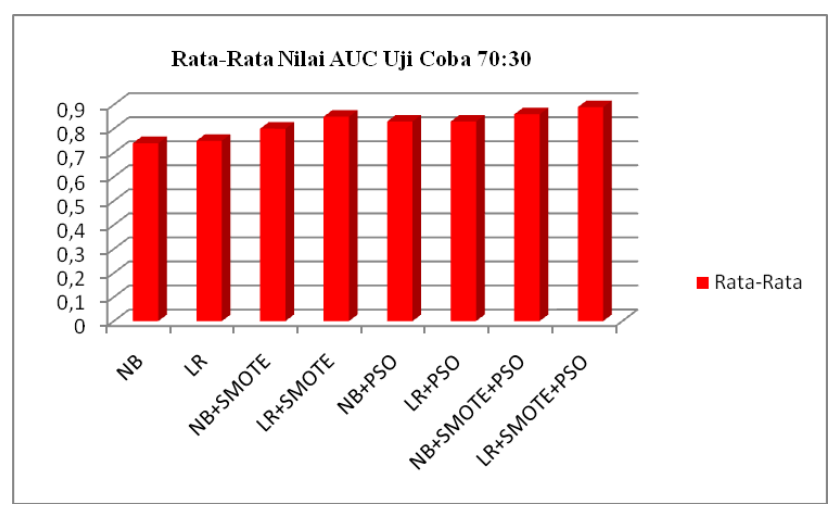

Gambar 9. Grafik rata-rata nilai AUC uji coba 60:40

Pada gambar 7 di atas dapat kita lihat jika model yang diusulkan memiliki nilai AUC rata-rata lebih baik daripada model lainnya dengan rata-rata nilai AUC pada naive bayes + SMOTE + PSO sebesar 0,86 dan LR+SMOTE+PSO sebesar 0,89 .

\section{KESIMPULAN}

Berdasarkan hasil dari uji coba yang telah dijabarkan sebelumnya dengan memanfaatkan integrasi teknik SMOTE pada nä̈ve bayes dan logistic regression berbasis PSO dapat diambil kesimpulan sebagai berikut : 
Model yang diusulkan secara rata-rata pada ujicoba dengan 8 dataset NASA mampu meningkatkan nilai AUC sebagai tolak ukur keberhasilan kinerja model klasifikasi.

Setelah dilakukan uji coba dengan menerapkan teknik uji dengan membagi data training dan testing yaitu 50:50, 60:40 dan 70:30 didapatkan hasil nilai AUC meningkat hampir pada setiap dataset dan secara rata-rata nilai AUC model yang diusulkan lebih baik dari model lainnya.

Pada hasil uji coba didapatkan bahwa pembagian data kedalam training testing 70 : 30 merupakan teknik pembagian yang lebih baik karena selain nilai AUC secara rata-rata lebih tinggi yaitu pada LR+SMOTE+PSO 0,89 dan NB+SMOTE+PSO 0,86, pada teknik pembagian ini juga seluruh nilai AUC tidak ada yang lebih rendah dibandingkan dengan model lain.

\section{DAFTAR PUSTAKA}

[1] L. Bergmane, J. Grabis, dan E. Žeiris, "A Case Study: Software Defect Root Causes," Inf. Technol. Manag. Sci., 2018, doi: 10.1515/itms-2017-0009.

[2] B. Turhan dan A. Bener, "Software defect prediction: Heuristics for weighted naïve bayes," in ICSOFT 2007 - 2nd International Conference on Software and Data Technologies, Proceedings, 2007.

[3] T. Sedano, P. Ralph, dan C. Peraire, "Software Development Waste," in Proceedings - 2017 IEEE/ACM 39th International Conference on Software Engineering, ICSE 2017, 2017, doi: 10.1109/ICSE.2017.20.

[4] A. A. Shenvi, "Defect prevention with orthogonal defect classification," in Proceedings of the 2nd India Software Engineering Conference, ISEC 2009, 2009, doi: 10.1145/1506216.1506232.

[5] T. O. A. Lehtinen, M. V. Mäntylä, J. Vanhanen, J. Itkonen, dan C. Lassenius, "Perceived causes of software project failures - An analysis of their relationships," Inf. Softw. Technol., 2014, doi: 10.1016/j.infsof.2014.01.015.

[6] M. McDonald, R. Musson, dan R. Smith, The Practical Guide to Defect Prevention. 2008.

[7] A. Iqbal $d k k$., "Performance analysis of machine learning techniques on software defect prediction using NASA datasets," Int. J. Adv. Comput. Sci. Appl., vol. 10, no. 5, hal. 300-308, 2019, doi: 10.14569/ijacsa.2019.0100538.

[8] T. Hall, S. Beecham, D. Bowes, D. Gray, dan S. Counsell, "A systematic literature review on fault prediction performance in software engineering," IEEE Transactions on Software Engineering. 2012, doi: 10.1109/TSE.2011.103.

[9] S. Canu dan A. Smola, "Kernel methods and the exponential family," Neurocomputing, 2006, doi:

10.1016/j.neucom.2005.12.009.

[10] T. Wang dan W. H. Li, "Naïve bayes software defect prediction model," in 2010 International Conference on Computational Intelligence and Software Engineering, CiSE 2010, 2010, doi: 10.1109/CISE.2010.5677057.

[11] R. S. Wahono dan N. Suryana, "Combining particle swarm optimization based feature selection and bagging technique for software defect prediction," Int. J. Softw. Eng. its Appl., vol. 7, no. 5, hal. 153-166, 2013, doi: 10.14257/ijseia.2013.7.5.16.

[12] T. M. Khoshgoftaar, K. Gao, A. Napolitano, dan R. Wald, "A comparative study of iterative and non-iterative feature selection techniques for software defect prediction," Inf. Syst. Front., vol. 16, no. 5, hal. 801-822, 2014, doi: 10.1007/s10796-013-9430-0.

[13] J. Han, M. Kamber, dan J. Pei, Data Mining: Concepts and TechniquesHan, J., Kamber, M., \& Pei, J. (2012). Data Mining: Concepts and Techniques. San Francisco, CA, itd: Morgan Kaufmann. https://doi.org/10.1016/B978-0-12381479-1.00001-0. 2012.

[14] N. V. Chawla, K. W. Bowyer, L. O. Hall, dan W. P. Kegelmeyer, "SMOTE: Synthetic minority over-sampling technique," J. Artif. Intell. Res., 2002, doi: 10.1613/jair.953.

[15] J. Li, S. Fong, dan Y. Zhuang, "Optimizing SMOTE by
Metaheuristics with Neural Network and Decision Tree," in Proceedings - 2015 3rd International Symposium on Computational and Business Intelligence, ISCBI 2015, 2016, doi: 10.1109/ISCBI.2015.12.

[16] C. W. Dawson, Projects in Computing and Information Systems. 2009.

[17] I. Arora, V. Tetarwal, dan A. Saha, "Open issues in software defect prediction," in Procedia Computer Science, 2015, doi: 10.1016/j.procs.2015.02.161.

[18] T. R. Patil, "Performance Analysis of Naive Bayes and J48 Classification Algorithm for Data Classification," Int. J. Comput. Sci. Appl. ISSN 0974-1011, 2013.

[19] A. Saleh, "Klasifikasi Metode Naive Bayes Dalam Data Mining Untuk Menentukan Konsentrasi Siswa," KeTIK, hal. 200-208, 2015.

[20] F. Minabari, J. Titaley, dan N. Nainggolan, "Pengaruh Pelayanan Di Fakultas Matematika dan Ilmu Pengetahuan Alam Terhadap Kepuasan Mahasiswa Fmipa Unsrat Menggunakan Logistik Ordinal," J. Mat. Dan Apl., vol. 8, no. 2, hal. 153-160, 2019.

[21] A. Salim, "Optimalisasi Regresi Logistik Pada Proses Klasifikasi Menggunakan Algoritma Genetika,” vol. 6, no. 2, hal. 50-55, 2019, doi: 10.25047/jtit.v6i2.109.

[22] Alberto Fernandez, Salvador Garcia, Francisco Herrera, dan Nitesh V. Chawla, "SMOTE for Learning from Imbalanced Data: Progress and Challenges, Marking the 15-year Anniversary," J. Artif. Intell. Res., 2018.

[23] Aries Saifudin, "Pendekatan Level Data dan Algoritma untuk Penanganan Ketidakseimbangan Kelas pada Prediks Cacat Software Berbasis Naïve Bayes," 2014.

[24] R. M. Chen dan H. F. Shih, "Solving university course timetabling problems using constriction particle swarm optimization with local search," Algorithms, vol. 6, no. 2, hal. 227-244, 2013, doi: 10.3390/a6020227.

[25] A. Luque, A. Carrasco, A. Martín, dan A. de las Heras, "The impact of class imbalance in classification performance metrics based on the binary confusion matrix," Pattern Recognit., 2019, doi: 10.1016/j.patcog.2019.02.023.

[26] J. Attenberg dan Ş. Ertekin, "Class imbalance and active learning," in Imbalanced Learning: Foundations, Algorithms, and Applications, 2013.

[27] X. Y. Liu dan Z. H. Zhou, "Ensemble methods for class imbalance learning," Imbalanced Learn. Found. Algorithms, Appl., hal. 61-82, 2013, doi: 10.1002/9781118646106.ch4. 